\title{
SBTool as a Tool for Creating a Concept of Energy Self-sufficient Buildings
}

\author{
SBTool jako nástroj tvorby konceptu \\ energeticky soběstačných budov
}

Tomáš Hlavsa

Ústav stavitelství, Fakulta architektury, Vysoké učení technické v Brně, Česká republika xahlavsa@seznam.cz

\begin{abstract}
Creating concepts of energy self-sufficient buildings (ESBs) is, besides passive houses, another hot topic, but the diversity of approaches to ESBs is much wider. The article describes the ways of understanding and defining ESBs, and the use of modified SBTool for assessing alternative designs of ESBs in draft form, especially with respect to their characteristics and sustainable development.
\end{abstract}

KEYWORDS: self-sufficient building; passive house; energy; sustainable development

ABSTRAKT: Tvorba konceptů energeticky soběstačných budov (dále ESB) je po pasivních domech dalším aktuálním tématem, avšak různorodost jejich pojetí je daleko širší. Př́íspěvek pojednává o způsobech chápání a definování ESB a o využití modifikovaného nástroje SBTool k posuzování variantních návrhů ESB ve fázi konceptů s ohledem zejména na jejich charakteristické vlastnosti a udržitelný rozvoj.

KLÍČOVÁ SLOVA: energeticky soběstačná budova; pasivní dům; energie; udržitelný rozvoj 


\section{Úvod}

Roztř́štěnost problematiky energeticky soběstačných budov (dále ESB) nám neumožňuje pevněji uchopit tento typ budov jako celek. Je velmi obtížné srovnávat ESB napojenou na technickou infrastrukturu $s$ domem $v$ panenské prrírodě, stejně jako dům vybavený nejmodernější technikou s inteligentními řídicími prvky s domem bez veškerých výdobytků moderní civilizace. Všechny tyto typy domů mohou splňovat základní podmínku ESB, jíž je energetická nezávislost, avšak nelze dále stanovit, jakým způsobem tento primární požadavek splnily a co se za ním v útrobách daného systému skrývá.

V prrípadě nízkoenergetických, pasivních či nulových domů je pro možnost používání výše zmíněného prŕivlastku zapotřebí naplnit řadu parametrů, z nichž nejznámějším je měrná potřeba tepla na vytápění stanovená pro nízkoenergetické domy na $50 \mathrm{kWh} \cdot \mathrm{m}^{-2} \cdot \mathrm{rok}^{-1}$, pro pasivní domy na $15 \mathrm{kWh} \cdot \mathrm{m}^{-2} \cdot \mathrm{rok}^{-1}$ a pro domy nulové na $5 \mathrm{kWh} \cdot \mathrm{m}^{-2} \cdot$ rok $^{-1}$. U pasivních domů dále sledujeme energetickou náročnost $\mathrm{z}$ hlediska primární energie, vyváženost míry zateplení obálky budovy zavedením parametru průměrný součinitel prostupu tepla a dále přehřívání vnitřních prostor domu (TNI 730329 2010). Tyto parametry si kladou za cíl dosáhnout snížení energetické náročnosti vyváženým řešením při zohlednění hlavních vlivů a měly by zabránit vytvoření návrhu splňujícího slepě jednu tabulkovou hodnotu, a to za každou cenu. U energeticky soběstačných domů můžeme sledovat tyto parametry také, ale navíc nás zajímá samotná míra energetické nezávislosti, kterou lze zajistit posilováním vlastních energetických zdrojů nebo investic do snižování energetických potřeb.

Cílem práce bylo stanovit vhodnost zvoleného konceptu, který by projektant měl uplatnit: zda snižovat provozní potřeby, nebo investovat do vlastních zdrojů. Rovněž důležitým úkolem práce je stanovit optimální úroveň energetické nezávislosti.

Vzhledem k širokému záběru je práce omezena na rodinné domy, navíc na konkrétně zvolený koncept, který byl vygenerován na základě současných požadavků stavebníků a projekční praxe autora. Vzhledem k takovému omezení je jasné, že výsledky práce nebudou dostatečně objektivní na to, aby umožnily paušalizovat pro tak různorodou skupinu stavitelství, jako je individuální bydlení - z tohoto důvodu je dalším cílem vytvořit a popsat metodiku posuzování a hodnocení konceptů dalších. Jako určující rámec posuzovaných kritérií a jednotlivých aspektů daných konceptů jsou použity hlavní teze trvale udržitelného rozvoje, jež jsou pevně zakotveny v naší i evropské legislativě. K tomu byl využit modifikovaný nástroj SBTool. 


\section{Definice zkoumaného prototypu domu}

V rámci porovnávání konceptů se hodnotí pouze ty části návrhu, které jsou specifické právě pro energeticky soběstačné budovy (dále ESB). Jedná se zejména o části návrhu mající vliv na energetickou bilanci. Hodnotí se také důsledky, které s těmito částmi návrhu př́mo souvisejí. Jelikož jsou však jednotlivé části návrhu navzájem propojené natolik, že počet možných variantních řešení je prakticky nekonečný, byl po vzoru způsobu tvorby referenčního domu v hodnocení průkazu energetické náročnosti budovy vybrán jeden konkrétní virtuální koncept domu s pevně danou typologií hmotovým, dispozičním a architektonickým řešením -, který se liší pouze svou energetickou koncepcí, a to jak v pasivních, tak v aktivních řešeních.

Jinak řečeno, jeden konkrétní tvarový koncept byl rozvinut do 5 variant lišících se svou energetickou náročností:

- dům s tepelnou obálkou na úrovni doporučených hodnot součinitelů prostupu tepla dle ČSN 73 0540-2 bez systému nuceného větrání s rekuperací (ČSN 73 0540-2 2011),

- dům s tepelnou obálkou na úrovni doporučených hodnot součinitelů prostupu tepla dle ČSN 73 0540-2 se systémem nuceného větrání s rekuperací (ČSN 73 0540-2 2011),

- dům s tepelnou obálkou na úrovni vyšších hodnot součinitelů prostupu tepla doporučených pro pasivní domy dle ČSN 73 0540-2 se systémem nuceného větrání s rekuperací (ČSN 73 0540-2 2011),

- dům s tepelnou obálkou na úrovni nižších hodnot součinitelů prostupu tepla doporučených pro pasivní domy dle ČSN 73 0540-2 se systémem nuceného větrání s rekuperací (ČSN 73 0540-2 2011),

- dům s tepelnou obálkou odpovídající hodnotám součinitelů prostupu tepla nulového domu se systémem nuceného větrání s rekuperací.

Pro těchto 5 základních variant bylo vytvořeno 5 konceptů pokrytí energetické potřeby, a to koncepty s $0 \%, 25 \%, 50 \%, 75 \%$ a $100 \%$ krytím energetických potřeb pomocí vlastních energetických zdrojů, čemuž odpovídá míra energetické soběstačnosti. Bylo tedy stanoveno 5 variant míry energetické soběstačnosti.

Celkem tak bylo nadefinováno 25 variant jednoho hmotového a dispozičního konceptu, které se budou porovnávat. 


\section{Úprava metodiky SBTool}

K hodnocení daných konceptů z hlediska trvale udržitelného rozvoje byla použita metodika SBToolCZ, což je národní metodika hodnocení komplexní kvality budov, kdy se posuzují vlastnosti budovy a okolí ve vazbě na udržitelný rozvoj (Vonka 2013). Pro potřeby hodnocení vlastností týkajících se právě a jenom ESB byla metodika upravena, a to zejména co se týče rozsahu řešených kritérií a systému přriřazování výsledných bodů.

Rozsah a způsob hodnocení je dán typem kriteriálních listů, algoritmem výpočtu jednotlivých indikátorů a jejich váhou. Kritéria se tak mohou v rámci metodiky lišit v závislosti na posuzovaném typu stavby. Jelikož tato práce pojednává o obytných stavbách, z nichž se omezila pouze na rodinné domy, byla vybrána i př́íslušná modifikace používané metodiky, a to SBToolCZ určený k posuzování rodinných domů. Následující tabulky určují rozsah posuzovaných kritérií a jim odpovídající váhy.

$\mathrm{V}$ rámci hodnoticího modelu stanoveného $\mathrm{v}$ této práci se pro potřeby porovnávání jednotlivých konceptů ESB nehodnotí kritéria E.08, E.09, E.10, E.11, E.12, E.13, E.14, S.01, S.02, S.03, S.04, S.05, S.07, S.08, S.09, S.11, S.12, S.13, C.02, C.03 a C.04 (v tabulkách jsou označena šedou barvou), a to $\mathrm{z}$ toho důvodu, že bud’ zásadním způsobem nezasahují do hlavních principů energeticky soběstačných budov, nebo mohou být pro všechny posuzované varianty stejná bez dopadu na výsledek, nebo je není možno posoudit s ohledem na rozsah hodnocených částí návrhu, a tím znalostí potřebných vstupních parametrů. Totéž platí i pro celou skupinu L, která do výsledného hodnocení nevstupuje ani v původní metodice.

$\mathrm{V}$ př́padě, kdy by se hodnotily návrhy s jiným rozsahem posuzovaných částí a bylo by $\mathrm{k}$ dispozici dostatečné množství vstupních parametrů, by bylo možné rozsah posuzovaných kritérií rozšířit nebo naopak zúžit.

Výsledné hodnocení nemodifikované metodiky SBTool je nastaveno absolutně a umožňuje hodnotit ve vzájemném srovnání různé typologicky odlišné druhy staveb pomocí pevně nastaveného měřítka. $\mathrm{V}$ momentě, kdy stejnou metodikou začneme hodnotit pouze část stavby, dostaneme výsledné hodnoty jiné, odpovídající poměrově pouze hodnocené části budovy. Obdobné zkreslení vzniká také tehdy, nehodnotíme-li všechna kritéria, ale pouze jejich výběr. Proto je k posuzování pouze částí stavby či kritérií použiváno hodnocení relativní, které spočivá pouze v porovnávání dílčích parametrů stavby na základě dílčího počtu kritérií, a to minimálně dvou a více variant. 


\section{Vyhodnocení jednotlivých variant}

Všechny indikátory všech hodnocených variant jsou převedeny pomocí výše popsané metody na bodové hodnocení. Každé bodové hodnocení se vynásobí váhovým koeficientem (váhy jednotlivých kritérií) a bodová hodnocení se sečtou dle jednotlivých kriteriálních skupin. Bodový součet skupiny se nakonec vynásobí váhovým koeficientem celé skupiny a body všech skupin se opět sečtou. Výsledné číslo je konečným hodnocením dané varianty modifikovanou metodikou SBToolCZ z hlediska trvale udržitelného rozvoje. Výše uvedený postup je dokladován konkrétními hodnotami v následujících tabulkách.

\section{Závěr}

Tato metodika nám umožňuje porovnávat pouze dílčí části návrhu nebo i soubory těchto dílčích částí, a pomáhá nám tak sledovat vyváženost systému, např. lze v daném konceptu zjistit bodové hodnocení př́pojky elektřiny a bodové hodnocení propanbutanového agregátu na základě sledování změn vstupních parametrů, kterými budou $\mathrm{v}$ tomto prrípadě třeba délka připojení, charakteristika agregátu, cena plynu či elektřiny, emisní a konverzní faktory obou zdrojů apod. Lze vysledovat, od jakých hodnot bude $\mathrm{z}$ hlediska trvale udržitelného rozvoje výhodnější propanbutanový agregát a při jakých podmínkách je vhodné ještě dům napojovat na veřejnou elektrickou sít. Velkou výhodou je fakt, že metodika funguje na základě vstupních parametrů, které jsou vzájemně provázány s výsledným kriteriálním bodovým hodnocením jednoduše pochopitelnými vzorci, a je tudíž možné sledovat míru změny bodového hodnocení v závislosti na prováděných změnách jednotlivých vstupních parametrů. V úvahu se také musí brát, že hodnocení je oproti absolutnímu hodnocení původní metodiky SBToolCZ prováděno relativně. Absolutní závěry tak lze činit pouze s ohledem na široký výběr posuzovaných vzorků, např́klad tak, jak to bylo provedeno $\mathrm{v}$ hodnocení energetických variant jednoho typu konceptu domu v této práci. I tak je nutné dodat, že vytváření paušalizujících závěrů z posouzení této práce se musí brát s jistou rezervou, nebơ je zde množství vstupních údajů, které jsou v čase rychle proměnné.

Další rovinou výsledků této práce je porovnání základních energetických variant konkrétního konceptu rodinného domu. Výsledky tohoto porovnání znázorňuje obrázek č. 2 . Z grafu vyplývá, že z hlediska trvale udržitelného rozvoje je vhodné koncipovat domy s nízkou potřebou energie a s vysokým podílem pokrytí této energie vlastními obnovitelnými zdroji energie (OZE). Optimální pokrytí se také pohybuje cca od $50 \%$ do $75 \%$, a to v závislosti na energetických potřebách. Čím je potřeba energie větší, tím více optimum podílu energetické soběstačnosti klesá $\mathrm{k}$ hodnotě 


\section{LEGENDA}

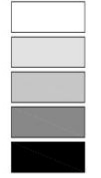

čistá podlahová plocha jednoho podlažl plocha fasády - okenni a dẹni výphĕ netransparentni plocha fasády plocha stavebnich konstrukci obodovèho plášté plocha vniťnich stavebnich konstrukci
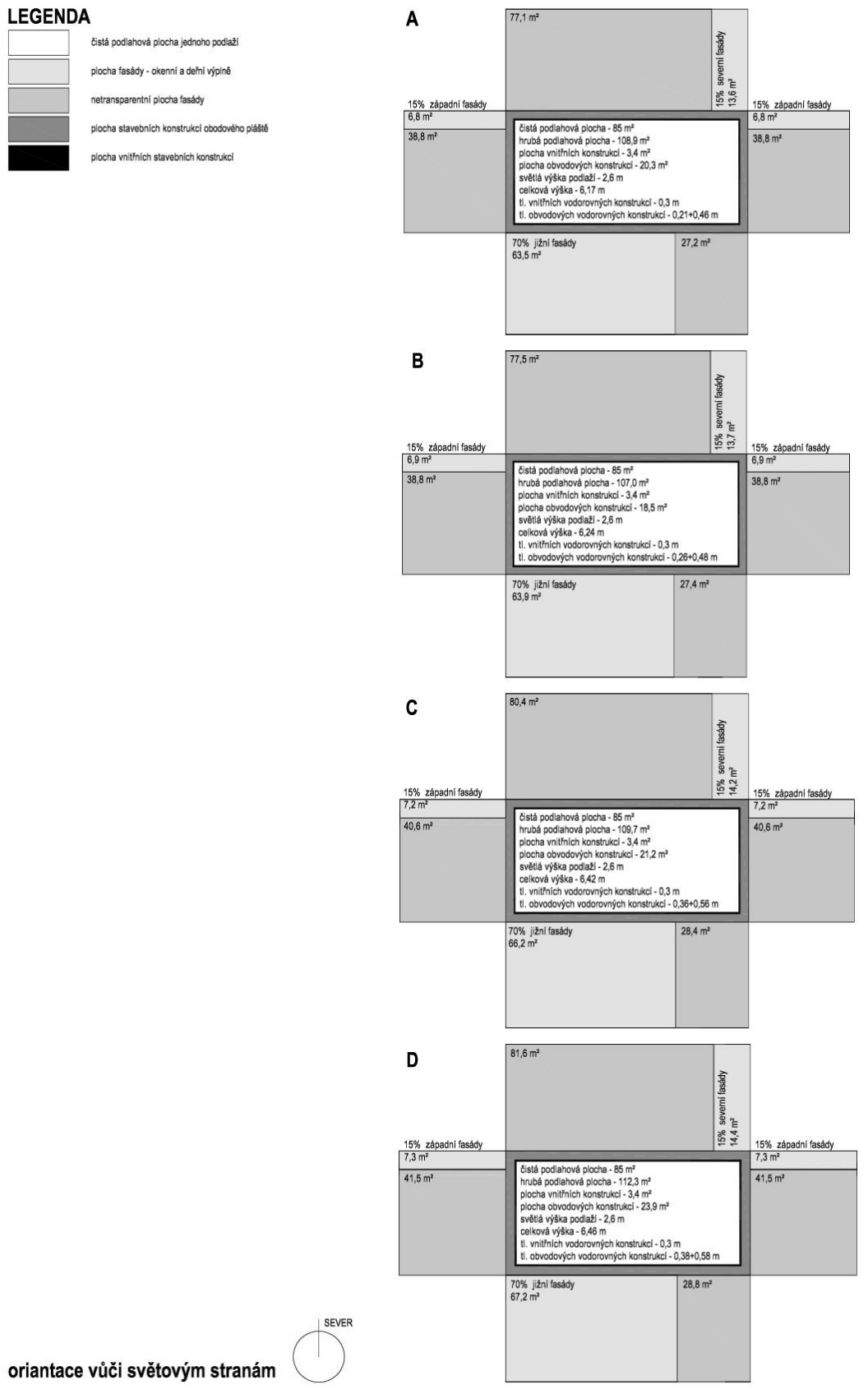
$50 \% .0 \%$ a $100 \%$ podíly energetické soběstačnosti jsou naopak nevhodné, a to zejména s ohledem na náklady na OZE zajištující $100 \%$ podíl energetické soběstačnosti či velkou zátěž životního prostředí v podobě velkého podílu energie získávané z veřejné elektrické sítě.

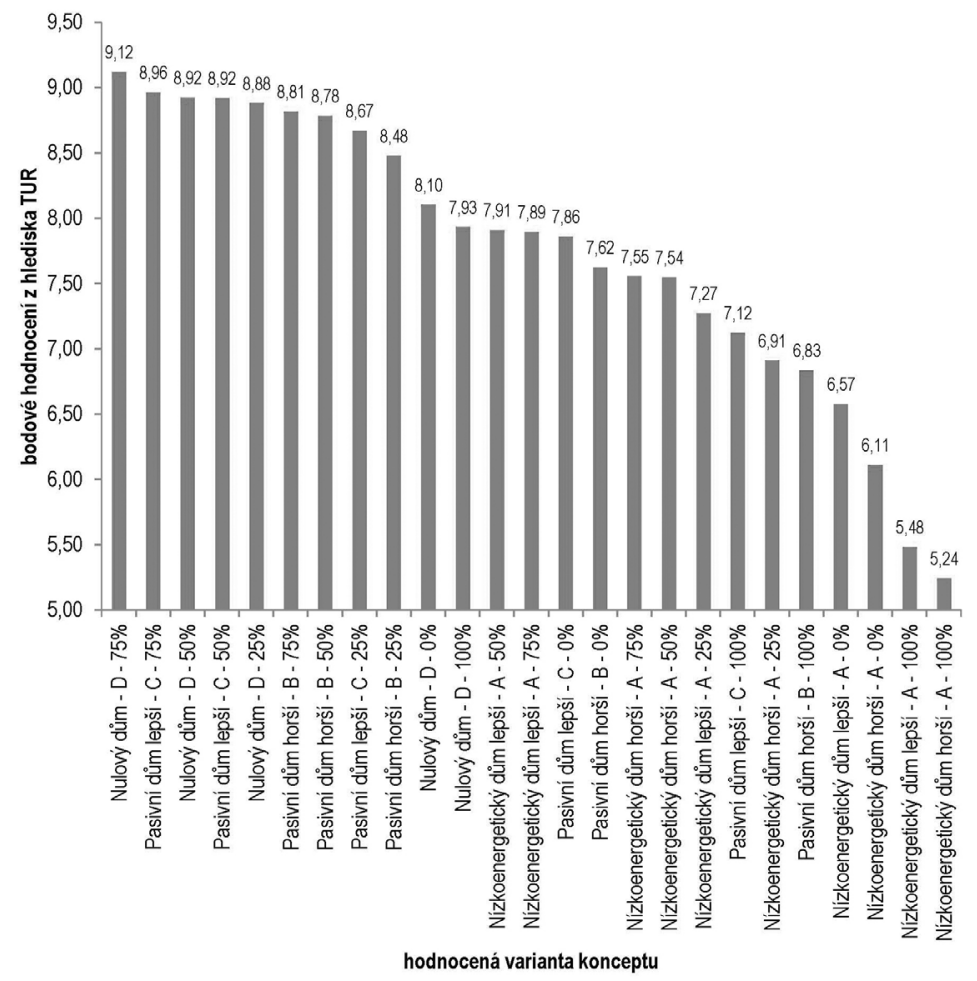

Obr. 2. Výsledné posouzení konceptů energeticky soběstačných rodinných domů hodnocení volby energetického konceptu domu na trvale udržitelný rozvoj modifikovanou metodikou SBToolCZ (Zdroj: autor)

Obr. 1. (vlevo) Grafické znázornění prostorových parametrů navržených variant hodnocených konceptů virtuálního domu (Zdroj: autor) 


\begin{tabular}{|c|c|c|c|c|c|c|}
\hline \multicolumn{2}{|l|}{ míra energeticke sobèstačnosti } & \multirow{2}{*}{$\begin{array}{c}0 \% \\
\text { [MJ/a] } \\
\end{array}$} & \multirow{2}{*}{$\begin{array}{c}25 \% \\
\text { [MJ/a] }\end{array}$} & \multirow{2}{*}{$\begin{array}{c}50 \% \\
\mathrm{MJ} / \mathrm{a}]\end{array}$} & \multirow{2}{*}{$\begin{array}{c}75 \% \\
\text { [MJ/a] } \\
\end{array}$} & \multirow{2}{*}{$\begin{array}{l}100 \% \\
{[\mathrm{MJ} / \mathrm{a}]}\end{array}$} \\
\hline ročni bilance energie & označní & & & & & \\
\hline $\begin{array}{l}\text { dodaná využitelná energie ze solárnich } \\
\text { kolektorù }\end{array}$ & $Q_{T K}$ & 0 & 0 & 9766.476 & 9766.476 & 9766.476 \\
\hline $\begin{array}{l}\text { dodaná wužitelná energie vyrobená } \\
\text { fotovoltaickým sys. }\end{array}$ & Q Qup & 0 & 15683.08 & 20692.12 & 18779.94 & 7819.02 \\
\hline $\begin{array}{l}\text { dodaná využitelná energie vyrobená větrnou } \\
\text { elektrárnou }\end{array}$ & QWE & 0 & 0 & 0 & 17887.25 & 44718.16 \\
\hline energie dodaná ze sitè & $Q_{\text {net }}$ & 62303.65 & 46620.58 & 31684.21 & 15771.2 & 0 \\
\hline $\begin{array}{l}\text { celková potřeba energie se započtenim } \\
\text { úcíinnosti systému }\end{array}$ & $Q_{\text {colk }}$ & 62303.65 & 62303.65 & 62142.8 & 62204.87 & 62303.65 \\
\hline
\end{tabular}

\section{VARIANTA A s VZT s rekuperaci}

\begin{tabular}{|c|c|c|c|c|c|c|}
\hline \multicolumn{2}{|l|}{ míra energetickè soběstačnosti } & $0 \%$ & $25 \%$ & $50 \%$ & $75 \%$ & $100 \%$ \\
\hline ročni bilance energie & označní & {$[\mathrm{MJ} / \mathrm{a}]$} & [MJ/a] & [MJ/a] & [MJ/a] & {$[\mathrm{MJ} / \mathrm{a}]$} \\
\hline $\begin{array}{l}\text { dodaná využitelná energie ze solárnich } \\
\text { kolektorư }\end{array}$ & $Q_{T K}$ & 0 & 0 & 9766.476 & 9766.476 & 9766.476 \\
\hline $\begin{array}{l}\text { dodaná využitelná energie vyrobená } \\
\text { fotovoltaickým sys. }\end{array}$ & QfvP & 0 & 14411.45 & 18860.8 & 15149.45 & 11652.62 \\
\hline $\begin{array}{l}\text { dodaná wyužitelná energie vyrobená větrnou } \\
\text { elektrámou }\end{array}$ & Qwe & 0 & 0 & 0 & 17887.25 & 35774.53 \\
\hline energie dodaná ze sitè & $Q_{\text {net }}$ & 57193.63 & 42782.15 & 28405.55 & 14291.64 & 0 \\
\hline $\begin{array}{l}\text { celková potřeba energie se započtením } \\
\text { úćinnosti systému }\end{array}$ & $Q_{\text {celk }}$ & 57193.63 & 57193.6 & 57032.82 & 57094.81 & 57193.63 \\
\hline
\end{tabular}

\section{VARIANTA B}

\begin{tabular}{|c|c|c|c|c|c|c|}
\hline míra energetické sobèstačnosti & & $0 \%$ & $25 \%$ & $50 \%$ & $75 \%$ & $100 \%$ \\
\hline roční bilance energie & Označní & [MJ/a] & [MJ/a] & [MJ/a] & [MJ/a] & [MJ/a] \\
\hline $\begin{array}{l}\text { dodaná využitelná energie ze solárnich } \\
\text { kolektorù }\end{array}$ & $Q_{T K}$ & 0 & 9765.756 & 9765.756 & 9765.756 & 9765.756 \\
\hline $\begin{array}{l}\text { dodaná wyužitelná energie vyrobená } \\
\text { fotovoltaickym sys. }\end{array}$ & Q & 0 & 0 & 11503.51 & 13198.28 & 6255.648 \\
\hline $\begin{array}{l}\text { dodaná využitelná energie vyrobená větrnou } \\
\text { elektrámou }\end{array}$ & Qwe & 0 & 0 & 0 & 8943.624 & 26830.91 \\
\hline energie dodaná ze sitě & $Q_{\text {net }}$ & 42950.23 & 32001.37 & 21202.78 & 10845.86 & 0 \\
\hline $\begin{array}{l}\text { celkova potřeba energie se započtenim } \\
\text { účinnosti systému }\end{array}$ & $Q_{\text {celk }}$ & 42950.23 & 41767.13 & 42472.04 & 42753.53 & 42852.31 \\
\hline
\end{tabular}

\section{VARIANTA C}

\begin{tabular}{|c|c|c|c|c|c|c|}
\hline \multicolumn{2}{|l|}{ míra energetickè soběstačnosti } & \multirow{2}{*}{$\begin{array}{c}0 \% \\
\text { [MJ/a] }\end{array}$} & \multirow{2}{*}{$\begin{array}{c}25 \% \\
{[M J / a]}\end{array}$} & \multirow{2}{*}{$\begin{array}{l}50 \% \\
{[M J / a]}\end{array}$} & \multirow{2}{*}{$\begin{array}{l}75 \% \\
\text { [MJ/a] }\end{array}$} & \multirow{2}{*}{$\begin{array}{l}100 \% \\
\text { MJJa] }\end{array}$} \\
\hline \multicolumn{2}{|l|}{\begin{tabular}{|l} 
míra energetické sobéstačnosti \\
ročni bilance energie \\
\end{tabular}} & & & & & \\
\hline \multicolumn{2}{|l|}{ dodaná yuzuzitelná energie ze solárních } & 0 & 9082.044 & 9766.476 & 9766.476 & 9766.476 \\
\hline $\begin{array}{l}\text { dodaná využitelná energie vyrobená } \\
\text { fotovoltaickým sys. }\end{array}$ & Q Qup & 0 & 0 & 8477.316 & 18576.94 & 10295.21 \\
\hline $\begin{array}{l}\text { dodaná využitelná energie vyrobená větrnou } \\
\text { elektrámou }\end{array}$ & QWE & 0 & 0 & 0 & 0 & 17887.25 \\
\hline energie dodaná ze sitè & $Q_{\text {not }}$ & 37962.11 & 27870.95 & 18694.76 & 9519.912 & 0 \\
\hline $\begin{array}{l}\text { celková potřeba energie se započtenim } \\
\text { účinnosti systému }\end{array}$ & $Q_{\text {celk }}$ & 37962.11 & 36952.99 & 36938.56 & 37863.32 & 37948.93 \\
\hline
\end{tabular}

\section{VARIANTA D}

\begin{tabular}{|c|c|c|c|c|c|c|}
\hline \multicolumn{2}{|l|}{ mira energeticke soběstačnosti } & $0 \%$ & $25 \%$ & $50 \%$ & $75 \%$ & $100 \%$ \\
\hline roční bilance energie & Označní & [MJ/a] & [MJ/a] & [MJ/a] & [MJ/a] & [MJ/a] \\
\hline $\begin{array}{l}\text { dodaná yuzüitelná energie ze solárnich } \\
\text { kolektorù }\end{array}$ & $Q_{T K}$ & 0 & 7980.7 & 7980.7 & 9766.5 & 9766.5 \\
\hline $\begin{array}{l}\text { dodaná yyužitelná energie vyrobená } \\
\text { fotovoltaickým sys. }\end{array}$ & QFvP & 0 & 0 & 8477.3 & 15446.1 & 15261.3 \\
\hline $\begin{array}{l}\text { dodaná využitelná energie vyrobená větrmou } \\
\text { elektrámou }\end{array}$ & Qwe & 0 & 0 & 0 & 0 & 8943.6 \\
\hline energie dodaná ze sitè & $Q_{\text {net }}$ & 33980.1 & 25112.7 & 16691.4 & 8606.8 & 0.0 \\
\hline $\begin{array}{l}\text { celková potřeba energie se započtenim } \\
\text { účinnosti systému }\end{array}$ & $Q_{\text {celk }}$ & 33980.1 & 33093.3 & 33149.4 & 33819.4 & 33971.4 \\
\hline
\end{tabular}

Tab. 1. Pokrytí energetických potřeb dle jednotlivých hodnocených variant - přehled výstupů z programu CALK (Zdroj: autor) 


\begin{tabular}{|c|c|}
\hline Skupina E - kritérium & Váha \\
\hline E.01 Spotřeba primární energie & $20,8 \%$ \\
\hline E.02 Potenciál globálního oteplováni & $9,6 \%$ \\
\hline E.03 Potenciál okyselováni prostředí & $5,2 \%$ \\
\hline E.04 Potenciál eutrofizace prostředí & $5,5 \%$ \\
\hline E.05 Potenciál ničení ozonové vrstvy & $4,4 \%$ \\
\hline E.06 Potenciál tvorby pǐizemního ozonu & $5,0 \%$ \\
\hline E.07 Výroba obnovitelné energie & $7,2 \%$ \\
\hline E.08 Použiti materiálů a výrobkũ pĭ výstavbě & $8,6 \%$ \\
\hline E.09 Hodnoceni stavebnich výrobkü & $6,1 \%$ \\
\hline E.10 Spotřeba pitná vody & $7,2 \%$ \\
\hline E.11 Zachycení deštové vody & $6,5 \%$ \\
\hline E.12 Využiti pozemku & $6,6 \%$ \\
\hline E.13 Zelen̆ na budovè a pozemku & $7,3 \%$ \\
\hline Celkem & $100 \%$ \\
\hline
\end{tabular}

Tab. 2. Váhy environmentálních kritérií (skupina E), (Zdroj: SBToolCZ)

\begin{tabular}{|l|c|}
\hline Skupina S - kritérium & Váha \\
\hline S.01 Vizuálni komfort & $10,0 \%$ \\
\hline S.02 Akustický komfort & $9,3 \%$ \\
\hline S.03 Tepelnà pohoda v letnim obdobi & $9,6 \%$ \\
\hline S.04 Tepelná pohoda v zimním obdobi & $4,6 \%$ \\
\hline S.05 Kvalita vnitřního vzduchu & $13,1 \%$ \\
\hline S.06 Ochrana proti radonu & $6,5 \%$ \\
\hline S.07 Zdravotni nezávadnost materiálů & $12,1 \%$ \\
\hline S.08 Uživatelský komfort & $6,8 \%$ \\
\hline S.09 Flexibilita využití budovy & $5,0 \%$ \\
\hline S.10 Prostorová efektivita & $4,9 \%$ \\
\hline S.11 Bezbariérové rešeni & $6,9 \%$ \\
\hline S.12 Mira oploceni pozemku & $4,7 \%$ \\
\hline S.13 Zabezpečeni obydli & $6,5 \%$ \\
\hline Celkem & $\mathbf{1 0 0 \%}$ \\
\hline
\end{tabular}

Tab. 3. Váhy sociálních kritérií (skupina S), (Zdroj: SBToolCZ)

\begin{tabular}{|l|l|}
\hline Skupina C - kritérium & Váha \\
\hline C.01 Náklady životniho cyklu & $39,8 \%$ \\
\hline C.02 Provădëci a provozni dokumentace & $19,6 \%$ \\
\hline C.03 Měreni spotřeb energii a vody & $20,1 \%$ \\
\hline C.04 Management triděného odpadu & $20,5 \%$ \\
\hline Celkem & $\mathbf{1 0 0} \%$ \\
\hline
\end{tabular}

Tab. 4. Váhy kritérií ve skupině ekonomika a management (skupina C), (Zdroj: SBToolCZ)

\begin{tabular}{|l|c|}
\hline Skupina L - kritérium & Váha \\
\hline L.01 Dostuphost veřejných míst pro relaxaci & $14,0 \%$ \\
\hline L.02 Dostupnost služeb & $17,0 \%$ \\
\hline L.03 Dostupnost veřejné dopravy & $21,0 \%$ \\
\hline L.04 Rizika lokality & $17,0 \%$ \\
\hline L.05 Kvalita mistriho ovzduši & $16,0 \%$ \\
\hline L.06 Prevence kriminality ve vystavéném prostředi & $15,0 \%$ \\
\hline Celkem & $\mathbf{1 0 0} \%$ \\
\hline
\end{tabular}

Tab. 5. Váhy kritérií ve skupině lokalita (skupina L), (Zdroj: SBToolCZ) 


\begin{tabular}{|c|c|c|c|c|c|c|c|c|c|c|c|c|}
\hline & 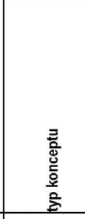 & 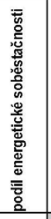 & 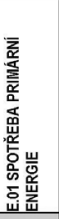 & 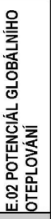 & 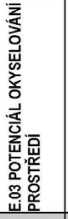 & 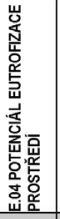 & 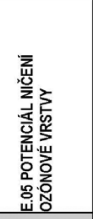 & 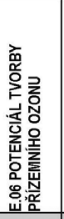 & 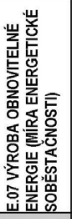 & 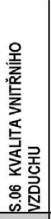 & 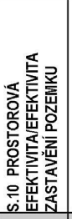 & 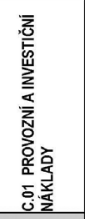 \\
\hline 1 & $D$ & $0 \%$ & 710.70 & 45.26 & 0.1057 & 0.0626 & $1.26703 \mathrm{E}-07$ & 0.00327 & $0.00 \%$ & 3.00 & 0.66 & $352.68 \mathrm{Kč}$ \\
\hline 2 & $D$ & $25 \%$ & 552.92 & 35.06 & 0.0842 & 0.0479 & $1.26703 \mathrm{E}-07$ & 0.00327 & $24.12 \%$ & 3.00 & 0.66 & $326.82 \mathrm{Kc}$ \\
\hline 3 & $D$ & $50 \%$ & 422.31 & 26.66 & 0.0652 & 0.0349 & 1.26703E-07 & 0.00327 & $49.65 \%$ & 3.00 & 0.66 & $515.80 \mathrm{Kc}$ \\
\hline 4 & $D$ & $75 \%$ & 294.92 & 18.47 & 0.0470 & 0.0224 & 1.26703E- 07 & 0.00327 & $74.55 \%$ & 3.00 & 1.24 & $640.32 \mathrm{Kč}$ \\
\hline 5 & 0 & $100 \%$ & 142.26 & 878 & 0.0253 & 0.0080 & 1.26703E-07 & 0.00327 & $100.00 \%$ & 3.00 & 5.88 & $1212.17 \mathrm{~K} \check{c}$ \\
\hline 6 & C & $0 \%$ & 766.71 & 49.17 & 0.1124 & 0.0699 & 1.29639E-07 & 0.00350 & $0.00 \%$ & 3.00 & 0.65 & $350.83 \mathrm{Kc \check {c }}$ \\
\hline 7 & C & $25 \%$ & 587.14 & 37.57 & 0.0880 & 0.0532 & 1.29639E-07 & 0.00350 & $24.58 \%$ & 3.00 & 0.65 & $342.37 \mathrm{Kc}$ \\
\hline 8 & C & $50 \%$ & 443.11 & 28.30 & 0.0672 & 0.0389 & 1.29639E- 07 & 0.00350 & $49.39 \%$ & 3.00 & 0.65 & $479.23 \mathrm{Kc}$ \\
\hline 9 & C & $75 \%$ & 303.46 & 19.34 & 0.0469 & 0.0250 & 1.29639E-07 & 0.00350 & $74.86 \%$ & 3.00 & 1.88 & $665.20 \mathrm{Kc \check {c }}$ \\
\hline 10 & C & $100 \%$ & 116.95 & 7.59 & 0.0207 & 0.0081 & 1.29639E- 07 & 0.00350 & $100.00 \%$ & 3.00 & 7.06 & $1490.29 \mathrm{Kc}$ \\
\hline 11 & $B$ & $0 \%$ & 845.07 & 54.68 & 0.1240 & 0.0791 & $1.11606 \mathrm{E}-07$ & 0.00257 & $000 \%$ & 3.00 & 0.63 & $349.51 \mathrm{Kc̆}$ \\
\hline 12 & B & $25 \%$ & 650.16 & 42.09 & 0.0975 & 0.0609 & 1.11606E- 07 & 0.00257 & $23.38 \%$ & 3.00 & 0.63 & 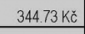 \\
\hline 13 & $\mathrm{~B}$ & $50 \%$ & 484.62 & 31.45 & 0.0734 & 0.0444 & 1.11606E-07 & 0.00257 & $50.08 \%$ & 3.00 & 0.63 & 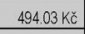 \\
\hline 14 & $B$ & $75 \%$ & 305.18 & 20.04 & 0.0478 & 0.0274 & $1.11606 \mathrm{E}-07$ & 0.00257 & $74.63 \%$ & 3.00 & 2.00 & $730.80 \mathrm{Kc}$ \\
\hline 15 & $B$ & $100 \%$ & 98.12 & 6.97 & 0.0186 & 0.0084 & 1.11606E-07 & 0.00257 & $100.00 \%$ & 3.00 & 765 & $1624.14 \mathrm{~K} \check{c}$ \\
\hline 16 & As VZT & $0 \%$ & 1088.82 & 71.81 & 0.1617 & 0.1053 & 1.18902E-07 & 0.00121 & $0.00 \%$ & 3.00 & 0.64 & $399.55 \mathrm{Kc \check {c }}$ \\
\hline 17 & A s VZT & $25 \%$ & 865.02 & 57.41 & 0.1291 & 0.0830 & 1.18902E-07 & 0.00121 & $25.20 \%$ & 3.00 & 0.64 & 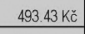 \\
\hline 18 & As VZT & $50 \%$ & 620.01 & 41.61 & 0.0953 & 0.0599 & 1.18902E-07 & 0.00121 & $50.19 \%$ & 3.00 & 1.41 & $620.08 \mathrm{Kc}$ \\
\hline 19 & As VZT & $75 \%$ & 362.09 & 25.27 & 0.0587 & 0.0358 & 1.18902E- 07 & 0.00121 & $74.97 \%$ & 3.00 & 3.29 & $968.21 \mathrm{Kč}$ \\
\hline 20 & As VZT & $100 \%$ & 101.52 & 8.75 & 0.0218 & 0.0115 & 1.18902E-07 & 0.00121 & $100.00 \%$ & 0.60 & 10.82 & $2017.17 \mathrm{~K} \check{c}$ \\
\hline 21 & A bez VZT & $0 \%$ & 1183.81 & 78.04 & 0.1756 & 0.1147 & 1. $18902 \mathrm{E}-07$ & 0.00121 & $0.00 \%$ & 0.60 & 0.64 & $392.21 \mathrm{Kc \check {c }}$ \\
\hline 22 & A bez VZT & $25 \%$ & 940.26 & 62.37 & 0.1402 & 0.0904 & 1.18902E- 07 & 0.00121 & $25.17 \%$ & 0.60 & 0.64 & $477.41 \mathrm{~K} \tilde{c}$ \\
\hline 23 & A bez VZT & $50 \%$ & 686.56 & 46.02 & 0.1051 & 0.0664 & 1. $18902 \mathrm{E}-07$ & 0.00121 & $49.01 \%$ & 0.60 & 1.53 & 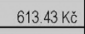 \\
\hline 24 & A bez VZT & $75 \%$ & 400.70 & 27.87 & 0.0645 & 0.0396 & 1. $18902 \mathrm{E}-07$ & 0.00121 & $74.65 \%$ & 0.60 & 3.65 & $987.90 \mathrm{KC̆}$ \\
\hline 25 & A bez VZT & $100 \%$ & 97.69 & 876 & 0.0218 & 0.0119 & 1.18902E-07 & 0.00121 & $100.00 \%$ & 0.60 & 11.18 & $2094.98 \mathrm{~K} \tilde{C}$ \\
\hline
\end{tabular}

Tab. 6. Přehled hodnot indikátorů všech kriteriálních listů všech hodnocených variant (Zdroj: autor) 


\begin{tabular}{|c|c|c|c|c|c|c|c|c|c|c|c|c|}
\hline \multicolumn{3}{|c|}{$\begin{array}{l}\text { hodnoty indikátorů pro } \\
\text { hodnoceni } 0 \text { body }\end{array}$} & \multirow[b]{2}{*}{ 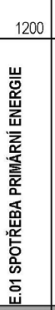 } & 80 & 0.18 & 0.11 & $6.60 \mathrm{E}-07$ & 0.00420 & 0 & 0 & 12.00 & \multirow[b]{2}{*}{ 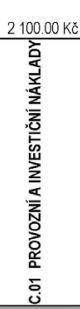 } \\
\hline & 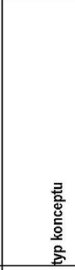 & 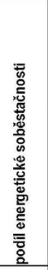 & & 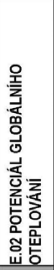 & 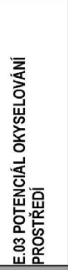 & 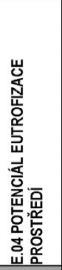 & 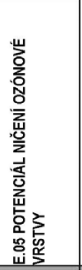 & 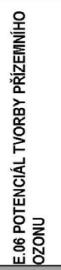 & 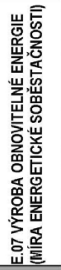 & 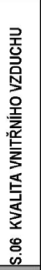 & 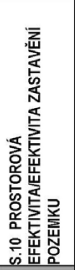 & \\
\hline 1 & D & $0 \%$ & 8.44 & 965 & 13.76 & 10.54 & 12.12 & 3.09 & 0.00 & 3.00 & 22.68 & 34.95 \\
\hline 2 & D & $25 \%$ & 11.16 & 12.48 & 17.74 & 13.80 & 12.12 & 3.09 & 2.41 & 3.00 & 22.68 & 35.46 \\
\hline 3 & D & $50 \%$ & 13.41 & 14.82 & 21.26 & 16.70 & 12.12 & 3.09 & 4.96 & 3.00 & 22.68 & 31,68 \\
\hline 4 & D & $75 \%$ & 15.60 & 17.09 & 24.62 & 19.47 & 12.12 & 3.09 & 7.46 & 3.00 & 21.53 & 29.19 \\
\hline 5 & D & $100 \%$ & 18.24 & 19.78 & 28.65 & 22.66 & 12.12 & 3.09 & 10.00 & 3.00 & 12.24 & 17.76 \\
\hline 6 & C & $0 \%$ & 7.47 & 8.56 & 12.51 & 8.91 & 12.05 & 2.35 & 0.00 & 3.00 & 22.71 & 34.98 \\
\hline 7 & c & $25 \%$ & 10.57 & 11.78 & 17.04 & 12.63 & 12.05 & 2.35 & 2.46 & 3.00 & 22.71 & 35.15 \\
\hline 8 & C & $50 \%$ & 13.05 & 14.36 & 20.89 & 15.79 & 12.05 & 2.35 & 4.94 & 3.00 & 22.71 & 3242 \\
\hline 9 & C & $75 \%$ & 15.46 & 16.85 & 24.65 & 18.89 & 12.05 & 2.35 & 7.49 & 3.00 & 20.24 & 28.70 \\
\hline 10 & C & $100 \%$ & 18.67 & 20.11 & 29.50 & 22.65 & 12.05 & 2.35 & 10.00 & 3.00 & 9.88 & 12.19 \\
\hline 11 & B & $0 \%$ & 6.12 & 703 & 10.37 & 6.87 & 12.46 & 5.43 & 0.00 & 3.00 & 22.74 & 35.01 \\
\hline 12 & B & $25 \%$ & 9.48 & 10.53 & 15.28 & 10.90 & 12.46 & 5.43 & 2.34 & 3.00 & 22.74 & 35.11 \\
\hline 13 & B & $50 \%$ & 12.33 & 13.48 & 19.74 & 14.57 & 12.46 & 5.43 & 5.01 & 3.00 & 22.74 & 32.12 \\
\hline 14 & B & $75 \%$ & 15.43 & 16.66 & 24.49 & 18.36 & 12.46 & 5.43 & 7.46 & 3.00 & 20.00 & 2738 \\
\hline 15 & B & $100 \%$ & 19.00 & 20.29 & 29.89 & 22.57 & 12.46 & 5.43 & 10.00 & 3.00 & 8.71 & 952 \\
\hline 16 & A s VZT & $0 \%$ & 1.92 & 228 & 3.39 & 1.04 & 12.30 & 9.96 & 0.00 & 3.00 & 22.72 & 34.01 \\
\hline 17 & As VZT & $25 \%$ & 5.78 & 6.28 & 9.42 & 6.00 & 12.30 & 9.96 & 2.52 & 3.00 & 22.72 & 32.13 \\
\hline 18 & $A s V Z T$ & $50 \%$ & 10.00 & 10.66 & 15.68 & 11.14 & 12.30 & 996 & 5.02 & 3.00 & 21.18 & 2960 \\
\hline 19 & A s VZT & $75 \%$ & 14.45 & 15.20 & 22.45 & 16.48 & 12.30 & 9.96 & 7.50 & 3.00 & 17.41 & 22.64 \\
\hline 20 & A s VZT & $100 \%$ & 18.94 & 19.79 & 29.30 & 21.88 & 12.30 & 9.96 & 10.00 & 0.60 & 2.35 & 166 \\
\hline 21 & A bez VZT & $0 \%$ & 0.28 & 0.54 & 0.81 & -1.05 & 12.30 & 9.96 & 0.00 & 0.60 & 22.72 & 34.16 \\
\hline 22 & A bez VZT & $25 \%$ & 4.48 & 4.90 & 7.37 & 4.34 & 12.30 & 9.96 & 2.52 & 0.60 & 22.72 & 32.45 \\
\hline 23 & A bez VZT & $50 \%$ & 8.85 & 9.44 & 13.86 & 9.68 & 12.30 & 9.96 & 4.90 & 0.60 & 20.94 & 29.73 \\
\hline 24 & A bez VZT & $75 \%$ & 13.78 & 14.48 & 21.39 & 15.64 & 12.30 & 9.96 & 7.46 & 0.60 & 16.71 & 22.24 \\
\hline 25 & A bez VZT & $100 \%$ & 19.01 & 19.79 & 29.29 & 21.79 & 12.30 & 996 & 10.00 & 0.60 & 1.65 & 0.10 \\
\hline
\end{tabular}

Tab. 7. Přehled převodu hodnot indikátorů na bodové ohodnocení (Zdroj: autor) 


\begin{tabular}{|c|c|c|c|c|c|c|c|c|c|c|c|c|}
\hline \multicolumn{3}{|c|}{ vahy jednotlivych kriterii } & $20.8 \%$ & $9.6 \%$ & $5.2 \%$ & $5.5 \%$ & $4.4 \%$ & $5.0 \%$ & $7.2 \%$ & $13.1 \%$ & $4.9 \%$ & $100.0 \%$ \\
\hline & 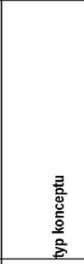 & 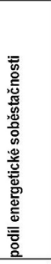 & 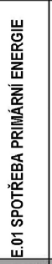 & 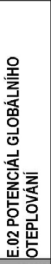 & 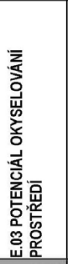 & 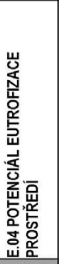 & 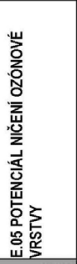 & 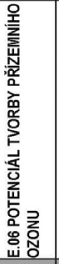 & 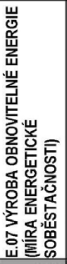 & 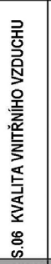 & 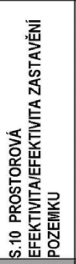 & 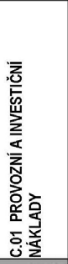 \\
\hline 1 & D & $0 \%$ & 1.75 & 0.93 & 0.72 & 0.58 & 0.53 & 0.15 & 0.00 & 039 & 1.11 & 34.95 \\
\hline 2 & D & $25 \%$ & 2.32 & 1.20 & 0.92 & 0.76 & 0.53 & 0.15 & 0.17 & 0.39 & 1.11 & 35.46 \\
\hline 3 & D & $50 \%$ & 279 & 1.42 & 1.11 & 0.92 & 0.53 & 0.15 & 0.36 & 0.39 & 1.11 & 31.68 \\
\hline 4 & D & $75 \%$ & 325 & 1.64 & 1.28 & 1.07 & 0.53 & 0.15 & 0.54 & 039 & 1.05 & 29.19 \\
\hline 5 & D & $100 \%$ & 3.79 & 1.90 & 1.49 & 1.25 & 0.53 & 0.15 & 0.72 & 039 & 0.60 & 17.76 \\
\hline 6 & C & $0 \%$ & 155 & 0.82 & 0.65 & 0.49 & 0.53 & 0.12 & 000 & 0.39 & 111 & 3498 \\
\hline 7 & c & $25 \%$ & 2.20 & 1.13 & 0.89 & 0.69 & 0.53 & 0.12 & 0.18 & 039 & 1.11 & 35.15 \\
\hline 8 & C & $50 \%$ & 271 & 1.38 & 109 & 0.87 & 0.53 & 0.12 & 036 & 0.39 & 111 & 32.42 \\
\hline 9 & C & $75 \%$ & 322 & 1.62 & 128 & 104 & 0.53 & 0.12 & 054 & 039 & 0.99 & 2870 \\
\hline 10 & C & $100 \%$ & 388 & 193 & 1.53 & 125 & 0.53 & 0.12 & 0.72 & 039 & 0.48 & 12.19 \\
\hline 11 & $B$ & $0 \%$ & 1.27 & 0.68 & 0.54 & 0.38 & 0.55 & 0.27 & 000 & 039 & 1.11 & 35.01 \\
\hline 12 & $B$ & $25 \%$ & 197 & 1.01 & 0.79 & 0.60 & 0.55 & 0.27 & 017 & 039 & 111 & 35.11 \\
\hline 13 & B & $50 \%$ & 257 & 1.29 & 1.03 & 0.80 & 0.55 & 0.27 & 0.36 & 039 & 1.11 & 32.12 \\
\hline 14 & $B$ & $75 \%$ & 321 & 1.60 & 1.27 & 1.01 & 0.55 & 0.27 & 054 & 039 & 0.98 & 2738 \\
\hline 15 & B & $100 \%$ & 3.95 & 1.95 & 1.55 & 1.24 & 0.55 & 0.27 & 0.72 & 0.39 & 0.43 & 9.52 \\
\hline 16 & A s VZT & $0 \%$ & 0.40 & 0.22 & 0.18 & 0.06 & 0.54 & 0.50 & 0.00 & 0.39 & 1.11 & 34.01 \\
\hline 17 & As VZT & $25 \%$ & 120 & 0.60 & 0.49 & 0.33 & 0.54 & 0.50 & 0.18 & 039 & 1.11 & 32.13 \\
\hline 18 & As VZT & $50 \%$ & 2.08 & 1.02 & 0.82 & 0.61 & 0.54 & 0.50 & 0.36 & 039 & 1.04 & 29.60 \\
\hline 19 & As VZT & $75 \%$ & 3.00 & 1.46 & 1.17 & 0.91 & 0.54 & 0.50 & 0.54 & 039 & 0.85 & 22.64 \\
\hline 20 & As VZT & $100 \%$ & 3.94 & 1.90 & 1.52 & 1.20 & 0.54 & 0.50 & 0.72 & 0.08 & 0.12 & 1.66 \\
\hline 21 & A bez VZT & $0 \%$ & 0.06 & 0.05 & 0.04 & -0.06 & 0.54 & 0.50 & 0.00 & 0.08 & 1.11 & 34.16 \\
\hline 22 & A bez VZT & $25 \%$ & 0.93 & 0.47 & 0.38 & 0.24 & 0.54 & 0.50 & 0.18 & 0.08 & 1.11 & 32.45 \\
\hline 23 & A bez VZT & $50 \%$ & 1.84 & 0.91 & 0.72 & 0.53 & 0.54 & 0.50 & 0.35 & 0.08 & 1.03 & 29.73 \\
\hline 24 & A bez VZT & $75 \%$ & 287 & 1.39 & 1.11 & 0.86 & 0.54 & 0.50 & 0.54 & 0.08 & 0.82 & 22.24 \\
\hline 25 & A bez VZT & $100 \%$ & 3.95 & 1.90 & 1.52 & 120 & 0.54 & 0.50 & 072 & 0.08 & 008 & 0.10 \\
\hline
\end{tabular}

Tab. 8. Přehled bodového ohodnocení se započtením váhových koeficientů jednotlivých kritérií (Zdroj: autor) 


\begin{tabular}{|c|c|c|c|c|c|c|}
\hline \multicolumn{3}{|c|}{ váhy jednotlivých skupin kritérii } & $50.0 \%$ & $35.0 \%$ & $15.0 \%$ & \\
\hline & 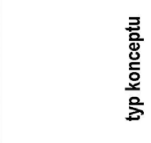 & 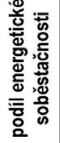 & ш & $\infty$ & 0 & \\
\hline 1 & $D$ & $0 \%$ & 2.33 & 0.53 & 5.24 & 8.10 \\
\hline 2 & D & $25 \%$ & 3.03 & 0.53 & 5.32 & 8.88 \\
\hline 3 & D & $50 \%$ & 3.64 & 0.53 & 4.75 & 8.92 \\
\hline 4 & D & $75 \%$ & 4.23 & 0.51 & 4.38 & 9.12 \\
\hline 5 & D & $100 \%$ & 4.92 & 0.35 & 2.66 & 7.93 \\
\hline 6 & $c$ & $0 \%$ & 2.08 & 0.53 & 5.25 & 7.86 \\
\hline 7 & C & $25 \%$ & 2.87 & 0.53 & 5.27 & 8.67 \\
\hline 8 & C & $50 \%$ & 3.53 & 0.53 & 4.86 & 8.92 \\
\hline 9 & $c$ & $75 \%$ & 4.17 & 0.48 & 4.30 & 8.96 \\
\hline 10 & C & $100 \%$ & 4.98 & 0.31 & 1.83 & 7.12 \\
\hline 11 & B & $0 \%$ & 1.84 & 0.53 & 5.25 & 7.62 \\
\hline 12 & B & $25 \%$ & 2.68 & 0.53 & 5.27 & 8.48 \\
\hline 13 & $B$ & $50 \%$ & 3.43 & 0.53 & 4.82 & 8.78 \\
\hline 14 & B & $75 \%$ & 4.22 & 0.48 & 4.11 & 8.81 \\
\hline 15 & $B$ & $100 \%$ & 5.12 & 0.29 & 1.43 & 6.83 \\
\hline 16 & A s VZT & $0 \%$ & 0.94 & 0.53 & 5.10 & 6.57 \\
\hline 17 & As VZT & $25 \%$ & 1.92 & 0.53 & 4.82 & 7.27 \\
\hline 18 & $A s \vee Z T$ & $50 \%$ & 2.97 & 0.50 & 4.44 & 7.91 \\
\hline 19 & $A s \vee Z T$ & $75 \%$ & 4.06 & 0.44 & 3.40 & 7.89 \\
\hline 20 & As VZT & $100 \%$ & 5.16 & 0.07 & 0.25 & 5.48 \\
\hline 21 & A bez VZT & $0 \%$ & 0.57 & 0.42 & 5.12 & 6.11 \\
\hline 22 & A bez VZT & $25 \%$ & 1.62 & 0.42 & 4.87 & 6.91 \\
\hline 23 & A bez VZT & $50 \%$ & 2.70 & 0.39 & 4.46 & 7.54 \\
\hline 24 & A bez VZT & $75 \%$ & 3.90 & 0.31 & 3.34 & 7.55 \\
\hline 25 & A bez VZT & $100 \%$ & 5.17 & 0.06 & 0.02 & 5.24 \\
\hline
\end{tabular}

Tab. 9. Výsledné hodnocení jednotlivých variant se započtením váhových koeficientů jednotlivých kriteriálních skupin (Zdroj: autor)

\section{Prameny}

TNI 730329. Zjednodušené výpočtové hodnocení a klasifikace obytných budov s velmi nízkou potřebou tepla na vytápění - Rodinné domy. Česká republika: Úřad pro technickou normalizaci, metrologii a státní zkušebnictví, 2010.

ČSN 73 0540-2. Tepelná ochrana budov - Část 2: Požadavky. 1. 10. 2011. Praha: Úřad pro technickou normalizaci, metrologii a státní zkušebnictví, 2011.

VONKA, Martin. SBToolCZ. 1. vyd. Praha: České vysoké učení technické v Praze, Fakulta stavební, c2013, 202 s. ISBN 978-80-01-05126-9. 